\title{
Presidentialisation: One Term, Two Uses - Between Deductive Exercise and Grand Historical Narrative
}

Political Studies Review

(c) The Author(s) 2018

Reprints and permissions: sagepub.co.uk/journalsPermissions.nav DOI: $10.1177 / 1478929918754500$ journals.sagepub.com/home/psrev

@SAGE

\section{Robert Elgie' $^{(D)}$ and Gianluca Passarelli²}

\begin{abstract}
This article focuses on the two main contributions to the contemporary academic debate about the term 'presidentialisation', namely the books by Samuels and Shugart and Poguntke and Webb. The aim is not to rehearse critiques that have already been made about this term or to add another to the list. Instead, the aim is to distinguish between two different ways in which the same term has been applied in the two studies. Both sets of authors are concerned with the same term, but each operationalises it in a different way. Acknowledging these differences allows us to focus on a specific aspect of Poguntke and Webb's account that is absent from Samuels and Shugart's, namely the construction of a grand historical narrative.
\end{abstract}

\section{Keywords \\ presidentialisation, constitutional regimes, grand narrative, party presidentialisation}

Accepted: 2nd January 2018

\section{Introduction}

This article examines the term 'presidentialisation'. There is now a large body of work on this topic (Dowding, 2013a, 2013b, 2013c; Foley, 2000, 2004, 2013; Kefford, 2013a, 2013b; Mughan, 2000; Passarelli, 2015b; Poguntke and Webb, 2005b; Samuels and Shugart, 2010; Webb and Poguntke, 2013). Some of this work questions the very usefulness of the term. For example, Dowding argues that the term 'prime ministerialisation' should be preferred at least in empirical studies that deal with processes of change in parliamentary systems such as Australia and Britain. By contrast, Karvonen (2010) and Garzia (2014) argue that contemporary processes of change can better be captured by the idea of 'personalisation'. These critiques are well known, and we do not wish to rehearse them here. Instead, we focus on the book by Samuels and Shugart (2010) and the edited

'School of Law and Government, Dublin City University, Dublin, Ireland

2Dipartimento di Scienze Politiche, Sapienza University, Roma, Italy

\section{Corresponding author:}

Robert Elgie, School of Law and Government, Dublin City University, Dublin 9, Ireland.

Email: robert.elgie@dcu.ie 
volume by Poguntke and Webb (2005b). We do so partly because both are very prominent contributions; the former having received nearly 400 Google Scholar citations and the latter nearly 1000 . Primarily, though, we choose them because both are centrally concerned with the idea of 'presidentialisation'. In that sense, they seem to be focusing on the same topic. However, we argue that each work employs the term in a very different way. Samuels and Shugart have a narrow focus on constitutional presidentialisation and party presidentialisation. They are engaged in an exercise in deductive political explanation that focuses on the effect of constitutional presidentialisation on party presidentialisation. By contrast, Poguntke and Webb refer to a more general idea of presidentialisation that results from a much broader process of social and political change. In effect, they are offering what amounts to a grand historical narrative. Thus, while both sets of authors are using the same term, they are referring to different meanings, outcomes and processes.

\section{Two Studies of Presidentialisation}

Both Poguntke and Webb (2005b) and Samuels and Shugart (2010) focus on the idea of 'presidentialisation'. For the former, this point could not be clearer. It is in the very title of their volume. This is not the case, though, for Samuels and Shugart. Nonetheless, the term appears on no fewer than 66 pages of their book. What is more, the authors define the concept of presidentialisation (Samuels and Shugart, 2010: 6). They acknowledge the distinction between presidentialisation and personalization (Samuels and Shugart, 2010: 249-250), making it clear that they are aware of the debate about the respective terms and arguing that presidentialisation is more appropriate for the purposes of their study. They also engage briefly with Poguntke and Webb's work on presidentialisation (Samuels and Shugart, 2010: 8, 17, and 249), implying that they are at least in part engaged in a similar exercise. However, the two studies think about the term 'presidentialisation' in very different ways. In the rest of this section, we try to capture the basic differences between the two studies in this regard.

\section{Samuels and Shugart: The Effect of Constitutional Presidentialisation on Party Presidentialisation}

Samuels and Shugart (2010: 6) define presidentialisation as 'the way the separation of powers fundamentally shapes parties' organizational and behavioral characteristics, in ways that are distinct from the organization and behavior of parties in parliamentary systems' (italics in the original). This definition highlights the two elements that they consider to be central to the idea. The first is what we can understand as 'constitutional presidentialisation', even though they do not use the term. The second is 'party presidentialisation', which is a term they employ on 20 pages of their book. We focus on these two elements.

Samuels and Shugart (2010: 37) understand constitutional presidentialisation as the degree to which the constitutional framework separates both the origin of the executive and legislative branches of government and their survival. They distinguish between four constitutional regimes in this regard, presidentialism, parliamentarism and two sub-types of semi-presidentialism, namely president-parliamentarism and premier-presidentialism (Shugart and Carey, 1992). They stress the fact that in a presidential regime both the president and the legislature are elected separately and the survival of each in office is independent of the other (Samuels and Shugart, 2010: 38). At the other end of the 
spectrum, in a parliamentary regime the prime minister and the legislature result from a single election, while the survival in office of the two institutions is also combined (Samuels and Shugart, 2010: 38). In between, they argue that the direct election of the president under semi-presidentialism is likely to lead to a greater degree of presidentialisation than under parliamentarism. However, they also argue that president-parliamentary regimes are likely to be more constitutionally presidentialised than premier-presidential regimes, given that in the former the president has the power, by definition, to dismiss the prime minister and cabinet, whereas in the latter the government is accountable solely to the legislature (Samuels and Shugart, 2010: 41). Thus, they argue that the degree of constitutional presidentialisation ranges ordinally from presidentialism as the most presidentialised system, through president-parliamentarism, to premier-presidentialism and finally to parliamentarism as the least presidentialised system, indeed as a system where constitutional presidentialisation in absent altogether.

Samuels and Shugart (2010: 37, emphasis in the original) then make a specific claim: 'to the extent that the constitutional structure separates executive and legislative origin and/or survival, parties will tend to be presidentialized'. That is to say, they argue that the degree of constitutional presidentialisation is mirrored in the degree of party presidentialisation. The term 'party presidentialisation' refers to the situation where political parties separate into two distinct branches, one in the executive and one in the legislature (Samuels and Shugart, 2010: 38). They assert that the level of party presidentialisation simply mirrors the extent of constitutional presidentialisation (Samuels and Shugart, 2010: 37), meaning that it varies in the same ordinal fashion. Thus, constitutional presidentialisation is the explanatory variable in their analysis the presidentialisation of party organisation, or party presidentialisation, is the main dependent variable. They hypothesise that the effect of constitutional presidentialisation on party presidentialisation manifests itself in various ways, namely that political outsiders are more likely to hold office as presidentialisation increases, that party influence over prime ministerial dismissal decreases as presidentialisation under semi-presidentialism increases, and that there are more violations of mandate representation as presidentialisation grows. To test their propositions, they rely primarily on identifying the statistical relationship between variation in constitutional presidentialisation and the behavioural effects of party presidentialisation.

In the context of this article, Samuels and Shugart's analysis raises certain issues. The first concerns the operationalization of constitutional presidentialisation. In an online review, Jack Blumenau (2012) unfairly criticised Samuels and Shugart for failing to move 'beyond a parliamentary/presidential dummy', stating that they remained 'trapped by the dichotomous distinction between regime-types'. We have seen that Samuels and Shugart do not simply employ a dummy variable for constitutional presidentialisation. Even so, it can take only four ordinal values in their empirical tests and, indeed, in some tests, it takes only three values because the number of president-parliamentary observations is so small that they have to be folded into the presidential category. So, while Blumenau's criticism may be unfair, the general point stands. Is the limited range of possible values in Samuels and Shugart's main explanatory variable sufficient to capture variation in constitutional presidentialisation? One way forward is to think of constitutional presidentialisation in a more fine-grained manner. There are now plenty of indices that try to measure the constitutional power of presidents. (For a review of the various indices and an aggregated index, see Doyle and Elgie, 2016). There are well-known problems with such indices (Fortin, 2013). Nonetheless, given Samuels and Shugart's 
primary explanatory variable is constitutional presidentialisation, it is at least plausible to ask whether there is an association between higher levels of presidential power measured in this way and party presidentialisation.

The second issue relates to the extent to which constitutional presidentialisation shapes party presidentialisation. Samuels and Shugart (2010: 16) do not make the deterministic claim that party presidentialisation '[follows] rigidly from regime-type'. All the same, they do make the bold claim that an analysis of differences in party organisation 'should begin with the difference in constitutional design' (Samuels and Shugart, 2010: 18), even if they also state that they 'do not claim that [their] argument supersedes or supplants the importance of social, economic, or cultural forces that drive party formation, evolution, and behavior'. Yet, if other factors matter, as they concede, then the question arises as to what factors matter, to what extent, and under what conditions? In this regard, Passarelli (2015a, 2015b) has argued that the 'genetic' features of political parties shape the effect of variation in presidentialisation. Following Panebianco, he includes the genetic origins of parties as an additional factor that explains variation in party presidentialisation. Three genetic features are important: (1) the organisation's construction and development, (2) the presence or the absence (at the party's origin) of an external 'sponsor' and (3) the role of charisma in the party's formation (Panebianco, 1988: 50-52). In Panebianco's words, a 'party's organizational characteristics depend more upon its history, i.e. on how the organization originated and how it consolidated, than upon any other factor' (Panebianco, 1988: 50). The logic of Passarelli's argument is that the genetic features of political parties can help to reinforce or attenuate the effects of constitutional presidentialisation on party presidentialisation.

Importantly, Passarelli's argument implies that there can be variation in party presidentialisation even within parliamentary regimes, something which Samuels and Shugart rule out at least in their empirical investigations. Indeed, the case studies in Passarelli's book suggest that in some parliamentary regimes a party's genetic features helped to overcome - albeit ephemerally - the lack of opportunity for party presidentialisation that the constitutional regime type places upon it. We might extend the logic of Passarelli's argument further still in this regard and include consideration of the process by which party leaders are selected. For instance, in parliamentary regimes such as Italy, there has been a move to open-style primary elections, while in others such as the Labour Party in Britain or the PSOE in Spain, there have been closed-style primaries, but ones in which there has still been a very high degree of participation. It is reasonable to expect that the degree of party presidentialisation may vary as a function of whether or not there are primary elections to select the party leader and perhaps even the type of primary election that is used. Such institutional changes may have an effect on the degree of party presidentialisation in both parliamentary regimes and, indeed, other regimes where the level of constitutional presidentialisation is greater.

The final issue relates to Samuels and Shugart's dependent variable. The standard way of interpreting their work is as an explanation of party organisation (e.g. Fruhstorfer, 2016). This is both because they explicitly frame their study in the context of the previous research on this topic going back to Duverger (Samuels and Shugart, 2010: 7-14) and because they make variation in constitutional presidentialisation the direct - although not deterministic - cause of differing party organisational structures. Yet, this makes the focus of their study relatively narrow. For sure, they show us that variation in party presidentialisation manifests itself in a variety of important ways, including the prevalence of political outsiders, the implementation of policies and the accountability of leaders. 
Nonetheless, for Samuels and Shugart, the term 'presidentialisation' is confined to the constitutional organisation of the separation of legislative powers and to the organisation of power within political parties.

\section{Poguntke and Webb: Presidentialisation as a Political Outcome}

Poguntke and Webb (2005a: 1) focus on what they perceive to be the phenomenon of the presidentialisation of politics. They say that presidentialisation 'denominates a process by which regimes are becoming more presidential in their actual practice without, in most cases, changing their formal structure, that is, their regime-type' (Poguntke and Webb, 2005a: 1). They go on to specify what they mean by regimes 'becoming more presidential', identifying three effects that they consider to be inherent to presidential regimes (Poguntke and Webb, 2005a: 5). They are an extensive set of leadership power resources, such that the head of the executive can govern without much outside interference; leadership autonomy, meaning that the head of the executive enjoys considerable autonomy from the party, even if this autonomy 'depends directly' on the head of the executive's electoral appeal; and the personalisation of the electoral process, whereby elections are 'decisively moulded' by the personalities of the main candidates at the election, rather than by constitutional provisions as Samuels and Shugart claim. This leads them to specify three 'central arenas of democratic government' that are primarily affected by these changes. They label them the executive face of presidentialisation, the party face and the electoral face. They then state that the process of presidentialisation 'means that these three faces of presidentialisation are amplified by factors other than those flowing directly from the formal constitutional structure' (Poguntke and Webb, 2005a: 5), confirming the idea that presidentialisation is occurring without constitutional change. Poguntke and Webb (2005a: 11) conclude this part of their analysis by claiming that 'the rate and extent of movement along the respective faces of presidentialisation may vary within (as well as between) countries', meaning that presidentialisation is not a binary or ordinal outcome, but a more graduated process. For them, there has been a general move towards presidentialisation over time.

For Poguntke and Webb, then, presidentialisation is the dependent variable. It is the result of a set of forces that are driving change that has an executive, party and electoral face. Thus, these forces are the main explanatory variables in their analysis. Poguntke and Webb then focus on the causes of presidentialisation. They state that '[i]n addition to contingent factors related to the political context and the personality of leaders' (Poguntke and Webb, 2005a: 13), there are a number of structural factors that 'are most important for explaining shifts towards a more presidentialised mode of governance in modern democracies'. They single out the following such factors: the internationalisation of politics, such as Europeanisation in that region and international summitry generally; the growth of the state, which has required a centralisation of resources within the core executive; the changing nature of mass communication, or the mediatisation of politics; and the erosion of traditional social cleavages, meaning that voters are less anchored than they were previously. They argue that particular structural changes are likely to have an effect on discrete faces of presidentialisation. For instance, the internationalisation of politics is likely to change only the executive face of presidentialisation (Poguntke and Webb, 2005a: 16). However, they also argue that certain structural changes can have a more general effect. For instance, they claim that the changing nature of mass communication will affect all three faces of presidentialisation. They finish by arguing that the three faces of 
presidentialisation can also affect each other, stating that 'it is possible that ... structural changes like the internationalization of politics give more executive power to leaders and this, in turn, may strengthen their electoral appeal and their ability to dominate their party' (Poguntke and Webb, 2005a: 17).

Having set up the idea of presidentialisation and its causes, the rest of the volume comprises mainly case studies of individual countries (Poguntke and Webb, 2005b). They confirm that the degree of presidentialisation has varied from one country to another. For example, there has been moderate change in Belgium, only a small change in Canada but from a high level of presidentialisation throughout, strong change in Germany and so on (Webb and Poguntke, 2005: 339). Even so, they state that they 'feel confident' that 'it is reasonable to talk of the "presidentialisation" of contemporary democracy" (Webb and Poguntke, 2005: 347) as a general process.

In the context of this article, three points about Poguntke and Webb's work are worth emphasising. The first relates to the term 'presidentialisation'. For them 'presidentialisation' describes a certain process of political change. They are clear that it is not an idea that can be understood as taking on a purely binary or ordinal form. There are many degrees of presidentialisation. At the same time, they acknowledge that the term is difficult to operationalise precisely. 'How, indeed, might one quantify presidentialisation itself in a precise and meaningful way?' they ask (Webb and Poguntke, 2005: 347). Similarly, in a statement that could apply to their understanding of the causes of presidentialisation too, they acknowledge that "[i]deally, further, more systematic verification would follow from our study, though we feel that there may be too many problems of operationalization for this to be feasible' (Webb and Poguntke., 2005: 351-352). For sure, they provide a list of certain indicators that can help to identify the degree of presidentialisation across the three faces of the term. Even so, they do not claim to provide an exhaustive list of such indicators and, in any event, the indicators themselves are difficult to quantify. In short, for Poguntke and Webb, 'presidentialisation' is an idea that captures something observable, but not something that is quantifiable.

The second issue relates to presidentialisation specifically as the dependent variable. As Dowding (2013c: 619) notes, Poguntke and Webb are making a behavioural claim, but what is the extent of the claim they are making? In one sense, presidentialisation would seem to be an assertion about a discrete political office, the chief executive in a country. In this regard, the focus is typically on the presidentialisation of prime ministers in parliamentary regimes. That said, Poguntke and Webb state very clearly that presidentialisation can occur in presidential regimes too (Webb et al., 2012: 81). To the extent that their thesis concerns a particular office, it might appear to have a relatively narrow import. At the same time, though, Poguntke and Webb's three faces of presidentialisation are extremely broad, comprising both the organisation of the executive branch of government as a whole, party politics, and electoral politics. So, Poguntke and Webb's book concerns the presidentialisation of politics more generally. The scope of their thesis is very broad.

The third issue concerns the causes of presidentialisation that Poguntke and Webb identify. They are engaged in a multifactorial study of leadership outcomes (Elgie, 2015). They identify four underlying structural causes, each of which is very broad. For example, the internationalisation of politics includes specific reference to international cooperation, globalisation, inter-governmental negotiation and, in Europe at least, Europeanisation. What is more, while each of these four general causes includes a wide range of factors, Poguntke and Webb also acknowledge that contingent causes, such as the personality of leaders and the political context, itself a catch-all category, also affect the three faces of presidentialisation. It is difficult to escape the conclusion that pretty 
much everything has at least the potential to be considered a cause of presidentialisation. The difference between their analysis and Samuels and Shugart's, who focus solely on constitutional and party presidentialisation could hardly be starker. Moreover, while Poguntke and Webb identify a wealth of causes, they also present what could be interpreted as a highly teleological argument. For example, they state that the processes underpinning the three faces of presidentialisation are 'logically connected' (Poguntke and Webb, 2005a: 11). This leads them to conclude that 'we are unlikely to find shifts in one face accompanied by complete stasis (or even counter-movement) in others' (Poguntke and Webb, 2005a: 11). In other words, in contrast to Samuels and Shugart who respond in advance to any criticism that they might be engaged in an exercise in institutional determinism, there is a sense in which Poguntke and Webb are more susceptible to the claim that they are describing a teleological process. Given the changes in the causal factors they identify, there would seem to be unidirectional movement towards at least some degree of presidentialisation.

\section{Two Forms of Presidentialisation}

We have seen that there is one term - presidentialisation - but two very different accounts of that term. Samuels and Shugart's book is a study of the effect of constitutional presidentialisation on party presidentialisation, whereas Poguntke and Webb's study is an account of societal presidentialisation more broadly understood. Yet, there is a more profound difference between the two studies. Samuels and Shugart are clearly situated towards the positivist end of the spectrum. They rely heavily on inferential statistics to validate hypotheses derived from their theory of presidentialisation. For their part, Poguntke and Webb are not engaged in such an exercise at all. This is not because they do not employ inferential statistics or because they acknowledge that it is difficult to quantify and operationalise the term 'presidentialisation'. After all, this is a challenge that faces many terms in the social sciences. It is because there is another sense in which Poguntke and Webb are not trying to explain a specific outcome at all, never mind finegrained variation in a particular outcome. Instead, they are presenting a grand historical narrative about the development of a contemporary phenomenon.

There is an epic quality to Poguntke and Webb's argument about the causes of presidentialisation. For example, they discuss the internationalisation of politics, the growth of the state, the changing structure of mass communication, and the erosion of traditional social cleavages. These are not overnight processes. They are long-term changes to the economic, social and political fabric of the world in which we live. Moreover, even though Poguntke and Webb discuss them separately, these processes are no doubt interdependent. The changing nature of mass communication has surely encouraged the erosion of traditional social cleavages and so forth. These interdependencies make it very difficult to engage in deductive political explanation. It is not merely that the causal processes are difficult to quantify, it is that they are not independent of each other. This makes them very challenging to model.

Poguntke and Webb's account of presidentialisation itself is no less grand. It includes consideration not just of the organisation of decision making within the executive branch, but also party politics, and election campaigning. Here, they are very explicit that developments in one of these three faces of presidentialisation can affect the other (Poguntke and Webb, 2005a: 17). The interdependence of the three faces of presidentialisation also distances their approach from the adopted by Samuels and Shugart. The electoral face is a dependent variable of certain causes, notably the erosion of traditional social cleavages, 
but it is also helps to explain why there has been a presidentialisation of the party face and the executive face. In this sense, it helps to explain the general process of presidentialisation too. Thus, we can see that there are complications with employing Poguntke and Webb's use of the term as an explanatory variable. However, if we think of Poguntke and Webb's account of presidentialisation as a grand historical narrative, then it takes on a different form. In this regard, it resembles Kirchheimer's (1966) argument about the rise of catch-all parties, or Katz and Mair's (1995) thesis about the rise of the cartel party. These studies point to similar multi-dimensional, inter-related, cross-national changes in political life. There is a teleological implication of Poguntke and Webb's analysis, precisely because they are telling us a story of how we went from 'A' to 'B' and how we are unlikely to go back to where we came from. The value of this type of study lies in the identification of a long-term process of political change.

\section{Conclusion}

Presidentialisation is an important phenomenon in comparative politics. We have focused on two of the most important original contributions to the study of this term, the books by Samuels and Shugart and Poguntke and Webb. We have suggested that even though they use the same term, they are engaged in quite distinct exercises. Samuels and Shugart are concerned with studying the specific impact of constitutional presidentialisation on party presidentialisation. By contrast, we believe it is better to think of Poguntke and Webb as presenting a grand narrative arc that addresses the development of a somewhat ineffable political idea. In this respect, we should think of their work more along the lines of Kirchheimer's story of the rise of catch-all parties, or even narratives about the effect of long-term historical processes, such as Weber's (1976) Peasants Into Frenchmen. We do not claim one of the two is better than the other in itself, rather we do claim that it is important to underline the theoretical and methodological differences between them. Appreciating the similarities and differences of the two studies allows the debate about presidentialisation to move forward on a firmer footing.

\section{Funding}

The author(s) received no financial support for the research, authorship and/or publication of this article.

\section{ORCID iD}

Robert Elgie (iD) https://orcid.org/0000-0001-5334-4796

\section{References}

Blumenau J (2012) Book Review: Presidents, Parties and Prime Ministers: How the Separation of Powers Affects Party Organization and Behaviour. LSE British Politics and Policy Blog, 23 September. Available at: http://blogs.lse.ac.uk/politicsandpolicy/book-review-presidents-parties-and-prime-ministers-how-theseparation-of-powers-affects-party-organization-and-behaviour/ (accessed 13 October 2017).

Dowding K (2013a) Beneath the Surface: Replies to Three Critics. Parliamentary Affairs 66: 663-672.

Dowding K (2013b) Presidentialisation Again: A Comment on Kefford. Australian Journal of Political Science 48 (2): $147-149$.

Dowding K (2013c) The Prime Ministerialisation of the British Prime Minister. Parliamentary Affairs 66: $617-635$.

Doyle D and Elgie R (2016) Maximizing the Reliability of Cross-National Measures of Presidential Power. British Journal of Political Science 46 (4): 731-741.

Elgie R (2015) Studying Political Leadership: Foundations and Contending Accounts. London: Palgrave Macmillan. 
Foley M (2000) The British Presidency: Tony Blair and the Politics of Public Leadership. Manchester: Manchester University Press.

Foley M (2004) Presidential Attribution as an Agency of Prime Ministerial Critique in a Parliamentary Democracy: The case of Tony Blair. The British Journal of Politics and International Relations 6 (3): 292-311.

Foley M (2013) Prime Ministerialisation and Presidential Analogies: A Certain Difference in Interpretive Evolution. Parliamentary Affairs 66: 655-662.

Fortin J (2013) Measuring Presidential Powers: Revisiting Existing Aggregate Measurement. International Political Science Review 34 (1): 91-112.

Fruhstorfer A (2016) Recent Debates and Advances in the Scholarly Examination of Presidential Institutions. French Politics 14: 254-271.

Garzia D (2014) Personalization of Politics and Electoral Change. Basingstoke: Palgrave Macmillan.

Karvonen L (2010) The Personalisation of Politics: A Study of Parliamentary Democracies. Colchester: ECPR Press.

Katz RS and Mair P (1995) Changing Models of Party Organization and Party Democracy: The Emergence of the Cartel Party. Party Politics 1 (1): 5-28.

Kefford G (2013a) A Rejoinder to Dowding. Australian Journal of Political Science 48 (2): 150-151.

Kefford G (2013b) The Presidentialisation of Australian Politics? Kevin Rudd's Leadership of the Australian Labor Party. Australian Journal of Political Science 48 (2): 135-146.

Kirchheimer O (1966) The Transformation of Western European Party Systems. In: LaPalombara J and Weiner M (eds) Political Parties and Political Development. Princeton, NJ: Princeton University Press, pp.177-200.

Mughan A (2000) Media and the Presidentialization of Parliamentary Elections. London: Palgrave Macmillan. Panebianco A (1988) Political Parties: Organization and Power. Cambridge: Cambridge University Press.

Passarelli G (2015a) Parties' Genetic Features: The Missing Link in the Presidentialization of Parties. In: Passarelli G (ed.) The Presidentialization of Political Parties. London: Palgrave Macmillan, pp.1-25.

Passarelli G (ed.) (2015b) The Presidentialization of Political Parties: Organizations, Institutions and Leaders. London: Palgrave Macmillan.

Poguntke T and Webb P (2005a) The Presidentialization of Politics in Democratic Societies: A Framework for Analysis. In: Poguntke T and Webb P (eds) The Presidentialization of Politics in Democratic Societies: A Framework for Analysis. Oxford: Oxford University Press, pp.1-25.

Poguntke T and Webb P (eds) (2005b) The Presidentialization of Politics in Democratic Societies: A Framework for Analysis. Oxford: Oxford University Press.

Samuels D and Shugart M (2010) Presidents, Parties, and Prime Ministers: How the Separation of Powers Affects Party Organization and Behavior. Cambridge: Cambridge University Press.

Shugart M and Carey J (1992) President and Assemblies: Constitutional Design and Electoral Dynamics. Cambridge: Cambridge University Press.

Webb P and Poguntke T (2005) The Presidentialization of Contemporary Democratic Politics: Evidence, Causes and Consequences. In: Poguntke T and Webb P (eds) The Presidentialization of Politics in Democratic Societies: A Framework for Analysis. Oxford: Oxford University Press, pp.336-356.

Webb P and Poguntke T (2013) The Presidentialisation of Politics Thesis Defended. Parliamentary Affairs 66: 646-654.

Webb P, Poguntke T and Kolodny R (2012) The Presidentialization of Party Leadership? Evaluating Party Leadership and Party Government in the Democratic World. In: Helms L (ed.) Comparative Political Leadership. London: Palgrave Macmillan, pp.77-98.

Weber E (1976) Peasants into Frenchmen: The Modernization of Rural France, 1870-1914. Stanford, CA: Stanford University Press.

\section{Author Biographies}

Robert Elgie is Paddy Moriarty Professor of Government and International Studies at Dublin City University, Ireland, and a Member of the Royal Irish Academy (MRIA). He has published numerous books, including Semipresidentialism: Sub-types and Democratic Performance (2011) and Political Leadership: A Pragmatic Institutionalist Approach (2018). He is the editor of the journal French Politics published by Palgrave.

Gianluca Passarelli is Associate Professor in Political Science at the Department of Political Sciences, Sapienza University, Roma. He is a member of Italian National Election Studies. His latest book is The Presidentialization of Political Parties (2015). He has published in Party Politics, Political Geography, Representation, and French Politics. He is the co-editor with Robert Elgie of the Presidential Politics book series with Palgrave. He is the convenor of the ECPR Standing Group on Presidential Politics. 